\title{
Hematological and Serum Biochemical Effects of Nursing on the Mother in Cynomolgus Monkeys (Macaca fascicularis)
}

\author{
Takashi YOSHIDA, Keiko OHTOH*, and Fumiaki CHO \\ Tsukuba Primate Center for Medical Science, The National Institute of Health, 1 Hachimandai, \\ Tsukuba-shi, Ibaraki 305 and ${ }^{*}$ The Corporation for Production and Research of \\ Laboratory Primates, 1 Hachimandai, Tsukuba-shi, Ibaraki 305, Japan
}

(Received 6 April 1992/Accepted 3 July 1992)

\begin{abstract}
The effects of nursing on maternal hematological and serum biochemical values were analyzed in cynomolgus monkeys reared in indoor cages at Tsukuba Primate Center. In our breeding system, infants are usually separated from their mothers at the age of 121 to 180 days. Mother monkeys of such infants were studied hematologically and biochemically (Group B), as were mother monkeys who happened to have nursed their infants past 181 days after parturition (Group A). During the period with their infants, mother monkeys in the latter group showed lower white blood cell counts (WBC) and higher red blood cell counts (RBC), hematocrit values $(\mathrm{Ht})$ and blood urea nitrogen concentrations (BUN) than the mother monkeys who had been separated from their infants. Also, serum calcum concentrations $(\mathrm{Ca})$ were decreased with prolonged nursing periods, indicating that lactation by the mother monkey probably continues even for a period from 181 days to about one year after parturition if she nurses her infant. Lactation during this period may accelerate hematogenesis and protein metabolism in the mother monkey. - KEY WORDS : cynomolgus monkey, hematology, lactation, serum biochemistry
\end{abstract}

\section{カニクイザルでの哺育が母体の血液学的および 血清生化学的測定值に及ぼす影響}

吉田高志・大籐圭子*·長 文昭

国立予防衛生研究所筑波医学実験用霊長類センター

*社団法人予防衛生協会

筑波医学実験用霊長類センターでは, 実験動物として のサル類の飼育・繁殖・育成をおこなっている。当セン ターで誕生した子カニクイザルは，実母による哺育をお こならことを原則とし，子ザルが 4 ないし 5 カ月龄頃に なると, 子ザルの体重や歯牙萌出状況, 固型飼料の摂取 状況, あるいは母ザルと離れての独立行動の有無を指標

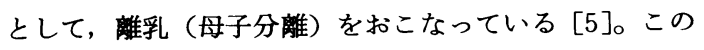
間の, 子ザルとの同居が母ザルの生理状態に及ぼす影響
については, ほとんど研究がされていない。我々は, サ ル類の生理状態を把握するために, 血液学的および血清 生化学的測定值（以下血液・血清生化学値と略す）を指 標として用いてきた [18-20]。乳牛では, 乳生産の観点 から, 泌乳中の母体の生理状態の管理, 特に栄養管理の 重要性が指摘されている [11]。ヒトでは, 産褯・授乳 期の婦人の栄養指導の必要性すいわれている [3]。しか し，泌乳あるいは母子の同居による影響を，血液・血清生 
Table 1. Numbers of animals examined

\begin{tabular}{ccccccc}
\hline \multirow{2}{*}{ Group $^{1)}$} & \multicolumn{6}{c}{ Days after parturition } \\
\cline { 2 - 7 } & $0-60$ & $61-120$ & $121-180$ & $181-240$ & $241-300$ & $301-365$ \\
\hline A & 15 & 14 & 31 & 33 & 36 & 21 \\
B & - & - & 10 & 34 & 24 & 13 \\
\hline
\end{tabular}

1) Group A : Numbers of mother monkeys kept with their infants (prolonged nursing group). Group B : Infants separated from their mothers at the age of 121 to 180 days. Numbers of mother monkeys separated from their infants are shown.

Table 2. Analytical methods and abbreviations

\begin{tabular}{lll}
\hline \multicolumn{1}{c}{ Item } & (Abbreviation) & \multicolumn{1}{c}{ Method } \\
\hline White blood cell count & (WBC) & Microcell counter method \\
Red blood cell count & $(\mathrm{RBC})$ & Microcell counter method \\
Hemoglobin concentration & $(\mathrm{Hb})$ & Cyanomethemoglobin method \\
Hematocrit value & $(\mathrm{Ht})$ & Microcell counter method \\
Mean corpuscular volume & $(\mathrm{MCV})$ & Microcell counter method \\
Mean corpuscular hemoglobin & $(\mathrm{MCH})$ & Microcell counter method \\
Mean corpuscular hemoglobin concentration & $(\mathrm{MCHC})$ & Microcell counter method \\
Platelet count & $(\mathrm{PLT})$ & Microcell counter method \\
White blood small cell ratio & $(\mathrm{W}-\mathrm{SCR})$ & Microcell counter method \\
White blood large cell ratio & $(\mathrm{W}-\mathrm{LCR})$ & Microcell counter method \\
White blood small cell count & $(\mathrm{W}-\mathrm{SCC})$ & Microcell counter method \\
White blood large cell count & $(\mathrm{W}-\mathrm{LCC})$ & Microcell counter method \\
Red blood cell distribution width & $(\mathrm{RDW}-\mathrm{SD})$ & Microcell counter method \\
Platelet distribution width & $(\mathrm{PDW})$ & Microcell counter method \\
Mean platelet volume & $(\mathrm{MPV})$ & Microcell counter method \\
Total protein concentration & $(\mathrm{TP})$ & Biuret reaction \\
Albumin concentration & $(\mathrm{Alb})$ & BCG method \\
Albumin-globulin ratio & $(\mathrm{A} / \mathrm{G})$ & Calculated from TP and Alb \\
Blood urea nitrogen concentration & $(\mathrm{BUN})$ & Urea-indophenol method \\
Glucose concentration & $(\mathrm{Glu})$ & Enzymatic method \\
Total cholesterol concentration & $(\mathrm{TChol})$ & Enzymatic method \\
Triglyceride concentration & $(\mathrm{TG})$ & Enzymatic method \\
Alkaline phosphatase activity & $(\mathrm{ALP})$ & Kind-King's method \\
Calcium concentration & $(\mathrm{Ca})$ & o-Cresolphthalein complex \\
\hline
\end{tabular}

化学値の測定によって把握しょうとする研究は, 未だな されていないよらである。サル類では, わずかに, 妊娠 中および分婏後での血液・血清生化学値を比較し, 報告 されているのみであり $[1,2,6]$, しかも，このような報 告では, 分婏後の母体の生理的な回復過程と, 泌乳や母 子同居による影響とが重複しているものと推測される。 ところで, 当センターにおいては, 1989年11月頃にカ ニクイザルのウイルス性感染症が発生し [16], その後 䄪半年間にわたって, 動物の移動の禁止の措置がとられ た。その結果, 分婏してから最長のもので約 1 年間にわ
たって離乳がおこなわれずに子ザルと同居し続けた母ザ ルが現れた。このような子ザルとの長期同居をしている 母ザルの血液・血清生化学值を解析することは, 子ザル との同居・授乳が母ザルの生理状態に及ぼす影響につい て調べるための格好のモデルとなり得るすのと考えられ る。そこで, 厳密に実験系を組み立てての研究ではない が，それらの母子を用いて検討を加えたので報告する。 なお，本研究に用いた母子の飼育されていた動物室にお いては, 上記の感染症ウイルスの伝播は, 血清学的に否 定されている。 
Table 3. Hematological values in female cynomolgus monkeys after parturition

\begin{tabular}{|c|c|c|c|c|c|c|c|}
\hline \multirow{2}{*}{ Item } & \multirow{2}{*}{ Group } & \multicolumn{6}{|c|}{ Days after parturition } \\
\hline & & $0-60$ & $61-120$ & $121-180$ & $181-240$ & $241-300$ & $301-365$ \\
\hline \multirow[t]{2}{*}{ WBC } & A & $77 \pm 17$ & $92 \pm 47$ & $73 \pm 32$ & $82 \pm 28$ & $73 \pm 24$ & $87 \pm 23$ \\
\hline & $\mathrm{B}$ & - & - & $99 \pm 26^{*}$ & $101 \pm 29^{*}$ & $99 \pm 31^{* *}$ & $71 \pm 18^{*}$ \\
\hline \multirow[t]{2}{*}{$\mathrm{RBC}$} & A & $653 \pm 44$ & $667 \pm 97$ & $660 \pm 100$ & $622 \pm 79$ & $646 \pm 83$ & $693 \pm 69$ \\
\hline & $\mathrm{B}$ & $-\cdots$ & - & $572 \pm 55^{*}$ & $592 \pm 72$ & $597 \pm 72^{*}$ & $599 \pm 75^{* *}$ \\
\hline \multirow[t]{2}{*}{$\mathrm{Hb}$} & A & $12.3 \pm 1.0$ & $13.2 \pm 2.0$ & $13.0 \pm 1.7$ & $12.1 \pm 1.3$ & $13.0 \pm 1.5$ & $13.4 \pm 1.9$ \\
\hline & $\mathrm{B}$ & - & - & $12.3 \pm 0.4$ & $12.1 \pm 1.3$ & $12.0 \pm 1.1^{*}$ & $12.3 \pm 0.9^{*}$ \\
\hline \multirow[t]{2}{*}{$\mathrm{Ht}$} & A & $43.6 \pm 3.7$ & $46.1 \pm 6.7$ & $44.3 \pm 5.9$ & $41.9 \pm 4.5$ & $44.2 \pm 4.7$ & $46.1 \pm 5.8$ \\
\hline & $\mathrm{B}$ & - & - & $38.8 \pm 1.8^{* *}$ & $39.2 \pm 4.4^{*}$ & $39.5 \pm 3.9^{* *}$ & $40.3 \pm 4.3^{* *}$ \\
\hline \multirow[t]{2}{*}{$\mathrm{MCV}$} & A & $66.8 \pm 2.8$ & $67.8 \pm 4.4$ & $67.4 \pm 4.4$ & $67.6 \pm 3.9$ & $68.7 \pm 4.9$ & $66.4 \pm 3.2$ \\
\hline & $\mathrm{B}$ & - & - & $68.2 \pm 4.2$ & $66.4 \pm 3.8$ & $66.4 \pm 3.1^{*}$ & $67.5 \pm 4.3$ \\
\hline \multirow[t]{2}{*}{$\mathrm{MCH}$} & A & $18.9 \pm 1.0$ & $19.8 \pm 1.8$ & $19.8 \pm 1.8$ & $19.5 \pm 1.4$ & $20.2 \pm 1.9$ & $19.3 \pm 1.6$ \\
\hline & B & - & - & $21.7 \pm 2.0^{* *}$ & $20.5 \pm 1.6^{*}$ & $20.3 \pm 1.2$ & $20.9 \pm 3.0$ \\
\hline \multirow[t]{2}{*}{$\mathrm{MCHC}$} & A & $28.4 \pm 1.7$ & $29.2 \pm 1.3$ & $29.3 \pm 1.3$ & $28.9 \pm 1.1$ & $29.4 \pm 1.1$ & $29.1 \pm 1.2$ \\
\hline & B & - & - & $31.8 \pm 1.0^{* *}$ & $30.9 \pm 1.6^{* *}$ & $30.5 \pm 1.2^{* *}$ & $30.8 \pm 2.9$ \\
\hline \multirow[t]{2}{*}{ PLT } & A & $43.8 \pm 13.0$ & $36.0 \pm 10.6$ & $40.3 \pm 10.5$ & $37.8 \pm 9.3$ & $36.9 \pm 8.8$ & $39.7 \pm 6.8$ \\
\hline & B & - & 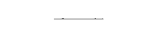 & $39.7 \pm 12.0$ & $36.6 \pm 8.8$ & $30.5 \pm 1.2^{* *}$ & $30.8 \pm 2.9^{* *}$ \\
\hline \multirow[t]{2}{*}{ W-SCR } & A & $38.0 \pm 16.2$ & $36.0 \pm 11.2$ & $40.4 \pm 11.3$ & $40.2 \pm 11.2$ & $42.5 \pm 12.1$ & $45.4 \pm 11.0$ \\
\hline & B & - & - & $46.1 \pm 8.0$ & $41.9 \pm 14.5$ & $42.8 \pm 13.4$ & $50.6 \pm 10.4$ \\
\hline \multirow[t]{2}{*}{ W-LCR } & A & $62.0 \pm 16.2$ & $64.0 \pm 11.2$ & $59.6 \pm 11.3$ & $59.8 \pm 11.2$ & $57.5 \pm 12.1$ & $54.6 \pm 11.0$ \\
\hline & $\mathrm{B}$ & - & - & $53.9 \pm 8.0$ & $58.1 \pm 14.5$ & $57.2 \pm 13.4$ & $49.4 \pm 10.4$ \\
\hline \multirow[t]{2}{*}{ W-SCC } & A & $28 \pm 11$ & $30 \pm 8$ & $30 \pm 18$ & $31 \pm 9$ & $32 \pm 16$ & $39 \pm 12$ \\
\hline & B & - & - & $46 \pm 16^{*}$ & $41 \pm 19^{* *}$ & $41 \pm 16^{*}$ & $36 \pm 11$ \\
\hline \multirow[t]{2}{*}{ W-LCC } & A & $49 \pm 21$ & $62 \pm 45$ & $43 \pm 20$ & $51 \pm 26$ & $41 \pm 15$ & $48 \pm 19$ \\
\hline & $\mathrm{B}$ & - & - & $52 \pm 15$ & $59 \pm 27$ & $57 \pm 26^{*}$ & $36 \pm 12^{*}$ \\
\hline \multirow[t]{2}{*}{ RDW-SD } & A & $33.9 \pm 2.2$ & $33.6 \pm 2.0$ & $34.0 \pm 2.5$ & $33.9 \pm 2.4$ & $33.3 \pm 2.1$ & $32.7 \pm 1.8$ \\
\hline & $\mathrm{B}$ & - & 工. & $31.8 \pm 1.0^{* *}$ & $32.1 \pm 1.7^{* *}$ & $32.7 \pm 2.1$ & $32.5 \pm 2.1$ \\
\hline \multirow[t]{2}{*}{ PDW } & A & $10.2 \pm 1.4$ & $11.1 \pm 2.3$ & $10.5 \pm 1.8$ & $11.5 \pm 1.9$ & $11.5 \pm 1.8$ & $11.3 \pm 1.7$ \\
\hline & B & - & 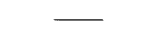 & $11.1 \pm 2.1$ & $11.4 \pm 1.9$ & $10.8 \pm 2.4$ & $10.6 \pm 1.9$ \\
\hline \multirow[t]{2}{*}{ MPV } & A & $9.6 \pm 0.8$ & $10.1 \pm 1.1$ & $9.9 \pm 1.2$ & $10.5 \pm 1.1$ & $10.5 \pm 1.0$ & $10.3 \pm 0.8$ \\
\hline & $\mathrm{B}$ & - & - & $10.3 \pm 1.3$ & $10.3 \pm 1.1$ & $9.9 \pm 1.3$ & $9.9 \pm 0.9$ \\
\hline
\end{tabular}

Asterisks denote statistically significant differences between $A$ and $B\left({ }^{* *} \mathrm{p}<0.01,{ }^{*} \mathrm{p}<0.05\right)$

\section{材料および方法}

使用動物：当センターで繁殖用種ザルとして使用さ れている成熟雌カニクイザル (Macaca fascicularis) を対象とした。それらは1989年11月以前に72時間の雌雄 同居方式により妊娠したもので，1990年 5 月から 6 月の 採血・測定時にはすべて正常分婏ののち, 子ザルと同居中
であった。母ザルには，分婏から 1 週後のるのから約 1 年後のものまでが含まれており, 計150頭である（Table 1)。比較の対象としては，1989年に当センターの定期 健康検査によって採血・測定された離乳後の母ザルの測 定値, 計81頭分を用いた。

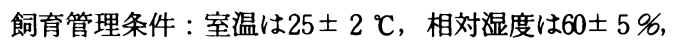
照明は 1 日 14時間照明 10 時間暗, 換気回数は 10回/時間 である。飼料は 1 日あたり，午前中に柑綗類およびリン 
Table 4. Serum biochemical values in female cynomolgus monkeys after parturition

\begin{tabular}{lccccccc}
\hline \multirow{2}{*}{ Item } & Group & \multicolumn{5}{c}{ Days after parturition } \\
\cline { 3 - 7 } & & $0-60$ & $61-120$ & $121-180$ & $181-240$ & $241-300$ & $301-365$ \\
\hline TP & A & $8.36 \pm 0.84$ & $9.07 \pm 0.42$ & $8.69 \pm 0.63$ & $8.80 \pm 0.57$ & $8.91 \pm 0.62$ & $8.75 \pm 0.52$ \\
& B & - & - & $8.05 \pm 0.44^{* *}$ & $8.17 \pm 0.47^{* *}$ & $8.20 \pm 0.34^{* *}$ & $8.00 \pm 0.32^{* *}$ \\
Alb & A & $4.27 \pm 0.38$ & $4.57 \pm 0.20$ & $4.46 \pm 0.24$ & $4.46 \pm 0.26$ & $4.56 \pm 0.32$ & $4.52 \pm 0.16$ \\
& B & - & - & $4.18 \pm 0.21^{* *}$ & $4.25 \pm 0.19^{* *}$ & $4.23 \pm 0.17^{* *}$ & $4.19 \pm 0.23^{* *}$ \\
A/G & A & $1.05 \pm 0.10$ & $1.01 \pm 0.08$ & $1.06 \pm 0.10$ & $1.03 \pm 0.08$ & $1.05 \pm 0.11$ & $1.07 \pm 0.10$ \\
& B & - & - & $1.09 \pm 0.12$ & $1.09 \pm 0.10^{*}$ & $1.06 \pm 0.09$ & $1.10 \pm 0.11$ \\
BUN & A & $15.3 \pm 3.1$ & $16.3 \pm 3.2$ & $17.0 \pm 3.2$ & $20.2 \pm 5.9$ & $16.6 \pm 3.3$ & $15.8 \pm 3.5$ \\
& B & - & - & $12.5 \pm 2.8^{* *}$ & $13.3 \pm 2.9^{* *}$ & $12.3 \pm 2.6^{* *}$ & $12.9 \pm 2.8^{*}$ \\
Glu & A & $45 \pm 9$ & $44 \pm 11$ & $51 \pm 12$ & $57 \pm 31$ & $55 \pm 12$ & $57 \pm 15$ \\
& B & - & - & $58 \pm 9$ & $51 \pm 11$ & $54 \pm 24$ & $49 \pm 11$ \\
TChol & A & $153 \pm 34$ & $149 \pm 36$ & $138 \pm 25$ & $152 \pm 38$ & $153 \pm 28$ & $150 \pm 28$ \\
& B & - & - & $156 \pm 36^{*}$ & $143 \pm 24$ & $124 \pm 27^{* *}$ & $138 \pm 28$ \\
TG & A & $91 \pm 95$ & $59 \pm 16$ & $69 \pm 36$ & $68 \pm 28$ & $62 \pm 30$ & $62 \pm 36$ \\
& B & - & - & $66 \pm 51$ & $64 \pm 49$ & $69 \pm 41$ & $68 \pm 39$ \\
ALP & A & $9.2 \pm 3.0$ & $10.7 \pm 4.0$ & $13.2 \pm 4.0$ & $12.5 \pm 4.6$ & $11.2 \pm 2.9$ & $10.5 \pm 2.6$ \\
& B & - & - & $13.2 \pm 3.2$ & $11.3 \pm 4.1$ & $9.9 \pm 3.6$ & $7.5 \pm 2.6^{* *}$ \\
& A & $9.3 \pm 0.9$ & $9.5 \pm 0.5$ & $8.5 \pm 0.8$ & $8.4 \pm 0.9$ & $7.9 \pm 0.6$ & $7.9 \pm 0.7$ \\
& B & - & - & $8.8 \pm 0.8$ & $9.0 \pm 0.7^{* *}$ & $9.3 \pm 0.8^{* *}$ & $9.1 \pm 0.8^{* *}$ \\
\hline
\end{tabular}

Asterisks denote statistically significant differences between $A$ and $B\left({ }^{* *} \mathrm{p}<0.01,{ }^{*} \mathrm{p}<0.05\right)$

ゴを各 $100 \mathrm{~g}$, 午後に市販サル用固型飼料 (AS 型, オリ エンタル酵母）約 $70 \mathrm{~g}$ を度に分けて与えた。個別ケー ジの大きさは，幅 $40 \times$ 縦 $60 \times$ 奥行き $60 \mathrm{~cm}$ である。動物 のケージ間の移動の禁止およびョード釆消毒薬による消 毒の徹底等の対策を施した以外の他の飼育管理方式は既 報のとおりである $[4] 。$

採血方法：採血にあたり，前日午後より絶食させ，当 日の午前中に大腿静脈より採血した。採血時には, 塩酸 ケタミン（ケタラール50, 三共）の筋肉内投与により動 物を麻酔後, シリコンコートした真空採血管を用いて採 血した。その一部 $(2.5 \mathrm{ml})$ を血球検査用としてあらか じめ EDTA-2 Na $5 \mathrm{mg}$ を入れた容器に移した。血球 検査は, 採血当日の午後に実施した。血清生化学検査 は, 血液を一晚 4 C で保存後, 2, 500rpm 15分間の遠心 分離により得た血清について実施した。

測定項目および測定方法：測定項目，その略称，およ び測定方法は, Table 2 に示した（以下，表中に示した 略号を用いる)。血球関係の測定は 15 項目で自動血球計数 装置（F-800，東㩊医用電子）を用いた。血清生化学的 測定は 8 項目であり自動分析装直（706，日立）を用い， カイノス製の試薬によった。なお， $\mathrm{A} / \mathrm{G}$ 比も算出した。
統計学的処理：動物は分婏後の日数によって60日每に 群分けし, 各項目毎に測定值の平均値とその標準偏差 (S.D.)をもとめた。分婏後 121 日以上の群については, 子ザルと同居している群 (A群) と離乳後の群 (B 群) との間で平均値の差の検定を実施した ( $\mathrm{t}$ 検定)。

\section{成}

いくつかの血液学的測定項目で, 子ザルと同居中の母 ザル（A群）と，離乳後の母ザル（B群）との間に有意 な差が検出された（Table 3)。同居中の母ザルの WBC は, 離乳後の母ザルに比べ低值を示した。しかし，分婏 後301日以上の群で, WBC は同居中の母ザルの方が離乳 後の母ザルよりも高値となり, それまでの関係が逆転し た。同居中の母ザルの WBC が低值を示していた期間 と一致して，小型白血球数 (W-SCC) む低值を示してい た。また RBC, $\mathrm{Ht}$ は離乳後の母ザルに比べて, 同居中 の母ザルのほうが, 高値を呈していた。この両群の間に おける， Hbには顕著な差がなく, MCH や $\mathrm{MCHC}$ が低 下している傾向が認められた。他方, 血清生化学值で両 群の間に顕著な差が検出された項目として, タンパク関 
連の項目をあげることができる（Table 4)。子ザルと 同居中の母ザルは, 分離後の母ザルに比べて, 明らか に高タンパク状態 (TP, Alb) を呈していた。しかし， $\mathrm{A} / \mathrm{G}$ 比については両群で大差が無いことから, 同居中 の母ザルでは血清グロブリン濃度も増加しているもの と推測される。タンパク代謝と関係するとされている BUN b, 同居中の母ザルで高值を呈していた。他方, Caは, 同居期間が長くなるにしたがって低下の傾向が 認められた。しかし, 母子分離後の母ザルでは, 離乳直 後の時期（分婏後121 180日）でやや低值が観察された ものの, その後速やかに回復する傾向が認められた。

\section{考寮}

本研究は, 当センターで発生したウイルス性感染症に ともなら動物の移動の禁止といら対策の中で, 結果的に 母子の同居が継続されてしまった母ザルを対象としてな された。そして, 感染の終息を確認するために, 発生後 約半年目におこなった検査で得られた測定値と母ザルの 分婏後日数, 即ち子ザルとの同居日数との関係を解析し たものである。そのような事情から，子ザルと同居中の 母ザルとして，150頭のカニクイザルを使用することが できたものの, 各群に属する個体数は最少の14頭から最 大の 36 頭まで約 2 倍の差となった。また, 離乳後の母ザ ルのデータは, 感染症の発生発見以前で, なるべく最近 おこなわれた検査の結果を流用することになった。その 為に, 対照群としての意味を持たせているものの, 採 血・測定の時期も異なり, 厳密な意味での対照群とはい えない。しかし，測定時に我々が括こなっている精度管 理によると, 本研究で差の検出された WBC, $\mathrm{Hb}, \mathrm{MCV}$ 等における変動係数 (C. V.) は $2 \%$ 以下であり, 血清生 化学関係では 2.6\%以下 [21] であることから, 時期の 違いがあるとはい充，両測定値は比較しらるものである と判断される。

一方，ラットでは泌乳期間の延長が母体におよぼす影 響について，母体構成成分の変化 [13]，摄食・摄水量 の变化 $[7,14]$ さらに内分泌学的变化 $[8,12,15]$ 等が 詳細に研究されている。しかし，ヒトを含めてサル類で は, そのような研究は報告されて打らず, わずかに, 分 婏後の変化として，一部の新世界ザル [10）や旧世界ザ ルであるアカゲザル [1], ブタオザル [6] そしてカニ クイザル [2] で報告されているのみである。さらに， いずれの場合も，子ザルの分離の状況との関連について は論じられていない。他方, 哺乳期間の延長と分婏後の 不妊期間との関係がアカゲザルで報告されている [17]。
しかし，カニクイザルの場合も，それ以外のマカク属サ ルの場合にも, 我々が知りらるこれらに関する情報は, ごく限られたものでしかない。そのよらな現状の中で, 本研究によって, 得られた情報は, 実験動物としてのカ ニクイザルを繁殖・育成するらえで有用なものであると 考える。

分離後の WBC の增加の理由については不明である が, 増加した白血球は大型白血球 (W-LCC ; 主に顆粒 球と思われる) ではなく小型白血球（W-SCC ; 主にリ ンパ球と思われる）に由来するすのと推測される。いず れにせよ, 離乳後に一過性に增加した WBC は, 半年後 にはもとの值にまで低下している。当センターで通常の 離乳を実施している母ザルにみられる WBC の一過性の 増加が，長期間の母子の同居をおこなった母ザルで離乳 後にも同じように見られるのかどらか，といら点につい ては今後, 改めて検討を加えたい。

妊娠中にヒトもカニクイザルも貧血傾向を呈する [2]。 しかし，カニクイザルでは，この負血傾向は，分婏後す みやかに回復する。そして, 子ザルとの同居中は, 赤血 球数増多の傾向を呈しているものと判断される。本研究 においてもこの赤血球数增多の傾向は, 子ザルの離乳に よってすみやかに消失するものの子ザルとの同居が続い ている期間中は維持された。さらに Ht にる增加の傾向 がみられたが，Hbにはあまり変化が無く，赤血球あた りのへモグロビン量や濃度 ( $\mathrm{MCH}, \mathrm{MCHC})$ の减少を伴 っていた。子ザルとの同居が続き, 泌乳・乳生産が母体 内で継続するために，母体の代謝活性が元進しているこ とが造血系に反映されているすのと推測される。

また，子ザルとの同居は，母体の血清フルブミン, グ ロブリン濃度の増加をもたらした。アルブミンもグロブ リンも乳汁の成分であり [11], これは乳生産に関係し た増加であると考えられる。さらに, BUN の増加にみ られるように, 子ザルと同居中の母ザルではタンパク代 謝系の活性む充進しているよ5である。そして, 同居期 間が長くなるに従って, 母体血清 $\mathrm{Ca}$ 㳻度が減少し続け た。分婏後 1 年間にわたって母体血清 $\mathrm{Ca}$ 漕度が減少し たことは, この間, 母体の乳生産・泌乳が継続している ことを意味しているものと考えられる。子ザルからの母 体乳首一の吸乳刺激が，母体の視床下部一下垂体系を経 て乳生産・泌乳の継続をもたらしているのであろう [7]。 飼育下のニホンザルでも分婏後 6 力月間は乳汁分泌が継 続すると報告されている [9]。

とはいえ本研究によって, 子ザルとの同居によって母 体の乳生産・泌乳が誘発され, 母体の造血系ならびにタ ンパク代謝の機能立進がもたらされることが示唆され 
た。このことは子ザルとの同居が継続するならば，1 年 間程度は持続するるのの，子ザルの分離によって比較的 速やかに低下するものと思われる。

\section{要 䄪}

カニクイザルでの小型ケージ内母子同居期間の延長が, 母体の血液学的および血清生化学的測定値におよぼす影 響について検討を加えた。分婏後121日目から180日目ま での間に母子分離（離乳）をおこならところを，最長約 1 年間にわたり離乳をおこなわなかった群では, 子ザル との同居中に, 白血球数の減少とともに赤血球数, へマ トクリット値, 血清タンパク量, 血清尿素態窒素量の増 加が見られた。また同居期間の延長にともなら血清カル シウム濃度の減少が観察された。子ザルとの同居によっ て母体の乳生産・泌乳，そして，造血系ならびにタンパ ク代謝系の機能元進をすたらしているものと結論された。

本論文を作成するにあたって，多くの御教示と資料の提供と を戴いた，信州大学農学部教授 太田克明博士に深謝いたしま す。

\section{文献}

[1] Allen, J. R. and Ahlgren, S. A.(1986). A comparative study of the hematologic change in pregnancy in the Macaca mulatta monkey and the human female. Am J. Obst \& Cyne c., 100, 894-903.

[2] Fujiwara, T., Suzuki, Y., Yoshioka, Y., and Honjo, S. (1974). Hematological changes during pregnancy and postpartum period in cynomolgus monkeys (Mac aca fascicularis). Exp. Animals 23, 137-146.

［3］橋口精範·天野和彦 (1979). 授乳婦の栄序管理. 妊産 婦栄養管理の寸べて, pp. 154-164，鈴木雅洲・坂元正一 監修, 南江堂, 東京.

[4] Honjo, S. (1985). The Japanese Tsukuba Primate Center (TPC) : An outline. J. med. Primatol, 14, 75-89.

［5］本庄重男・長 文昭（1977）。林属サル，実験動物 学 技術編, pp.312-346, 田嶋嘉婎編集, 朝倉書店, 東 京.

[6] McMahan, M. R., Clarkson, T. B., Sackett, G. P., and Rudel, L. L. (1980). Changes in plasma lipids and lipoprotein in Macaca ne mestrina during pregnancy and the postpartum period. Proc. Soc. Exp. Biol Med, 164, 199-206.
[7] 太田克明 (1981)，妊娠，泌乳動物の摂食量。家畜繁殖 誌, 27, 19-30.

[8] Ôta, K., Harai, Y., Unno, H., Sakauchi, S., Tomogane, H., and Yokoyama, A. (1974). Corticosterone secretion in response to suckling at various stages of normal and prolonged lactation in rats. J. Endocr. 62, 679-680.

[9] Ôta, K., Makino, Y., Kimura, M., and Suzuki, J. (1991). Lactation in the Japanese monkey (Macaca fuscata): Yield and composition of milk and nipple preference of young. Primates 32, 35-48.

[10］須崎百合子・吉田高志 (1988)。タマリン属サルの血液 および血清生化学値の妊娠にともなら变化。実験動物, 37, 303-309.

[11］田先威和夫 (1968)。泌乳と栄養。泌乳, pp. 383-416, 星 久四郎·内藤元男編集, 東大出版会, 東京.

[12] Tassanawat, T., Ôta, K., and Yokoyama, A. (1990). Changes in the responses of prolactin and corticosterone secretion to suckling at variouss stages of prolonged lactation in intact and ovariectomized rats. Jpn. J. Anim Reprod, 36, 88-92.

[13] Tassanawat, T., Ôta, K., and Yokoyama, A. (1990). Changes in body composition of mother rats during normal and prolonged lactation. Jpn. J. Anim Reprod, 36, 93-98.

[14] Tomogane, H., Ôta, K., Unno, H., and Yokoyama, A. (1976). Changes in body weight, milk production, food and water consumptions and vaginal semears in rats during prolonged lactation. Endocrinol Japan 23, 129-136.

[15] Tomogane, H., Ôta, K., and Yokoyama, A. (1976). Duration of diestrous period and secretion of progestins during prolonged lactation in the rat. Endocrinol Japan 23, 137-141.

[16） TPC ニュース 特集 (1990)。 サル水痘様ヘルペスウイ ルス感染症. TPC NEWS, 9.

[17] Wilson, M. E., Walker, M. L., Pope, N. S., and Gordon, T. P. (1988). Prolonged lactational infertility in adolescent rhesus monkeys. Biol Reprod 38, 163174.

[18] Yoshida, T. (1981). The changes of hematological and biochemical properties in cynomolgus monkeys (Macaca fascicularis) after importation. Jpn. J. Med Sci Biol, 34, 239-242.

［19］吉田高志・鈴木絹江・長 文昭・本庄重男（1986）。実 験用カニクイザルの成長にともなら血液学的および血清 生化学的測定値の変化. 実験動物, 35, 329-338.

［20］吉田高志・鈴木絹江・清水利行 - 長 文昭·本庄重男 (1986).メス・カニクイザル (Macaca fascicularis)の 血液性状におよほすケタミン麻酔の影響. 実㪘動物, 35, 455-461.

［21］吉田高志（1990）。室内繁殖・育成されたカニクイザル の成長. 成長, 29, 75-118 